\title{
Influence of Vitamin D Binding Protein on Accuracy of 25-Hydroxyvitamin D Measurement Using the ADVIA Centaur Vitamin D Total Assay
}

\author{
James Freeman, Kimberly Wilson, Ryan Spears, Victoria Shalhoub, and Paul Sibley \\ Siemens Healthcare Diagnostics, 511 Benedict Avenue, Tarrytown, NY 10591, USA \\ Correspondence should be addressed to James Freeman; james.freeman@siemens.com
}

Received 13 December 2013; Revised 7 April 2014; Accepted 28 April 2014; Published 19 June 2014

Academic Editor: Arthur Santora

Copyright (c) 2014 James Freeman et al. This is an open access article distributed under the Creative Commons Attribution License, which permits unrestricted use, distribution, and reproduction in any medium, provided the original work is properly cited.

\begin{abstract}
Vitamin D status in different populations relies on accurate measurement of total serum 25-hydroxyvitamin $\mathrm{D}$ [25(OH)D] concentrations [i.e., $25(\mathrm{OH}) \mathrm{D}_{3}$ and $25(\mathrm{OH}) \mathrm{D}_{2}$ ]. This study evaluated agreement between the ADVIA Centaur Vitamin D Total assay for $25(\mathrm{OH}) \mathrm{D}$ testing (traceable to the NIST-Ghent reference method procedure) and a liquid chromatography tandem mass spectrometry (LC-MS/MS) method for various populations with different levels of vitamin D binding protein (DBP). Total serum $25(\mathrm{OH}) \mathrm{D}$ concentrations were measured for 36 pregnant women, 40 hemodialysis patients, and 30 samples (DBP-spiked or not) from healthy subjects. ELISA measured DBP levels. The mean serum DBP concentrations were higher for pregnancy $(415 \mu \mathrm{g} / \mathrm{mL})$ and lower for hemodialysis subjects $(198 \mu \mathrm{g} / \mathrm{mL})$ than for healthy subjects and were highest for spiked serum $(545 \mu \mathrm{g} / \mathrm{mL})$. The average bias between the ADVIA Centaur assay and the LC-MS/MS method was $-1.4 \%$ (healthy), $-6.1 \%$ (pregnancy), and $4.4 \%$ (hemodialysis). The slightly greater bias for samples from some pregnancy and hemodialysis subjects with serum DBP levels outside of the normal healthy range fell within a clinically acceptable range - reflected by analysis of their low-range $(\leq 136 \mu \mathrm{g} / \mathrm{mL}), \mathrm{medium}$ range $(137-559 \mu \mathrm{g} / \mathrm{mL})$, and high-range $(\geq 560 \mu \mathrm{g} / \mathrm{mL})$ DBP groups. Thus, the ADVIA Centaur Vitamin D Total assay demonstrates acceptable performance compared with an LC-MS/MS method for populations containing different amounts of DBP.
\end{abstract}

\section{Introduction}

Increasing awareness of the important role of vitamin $\mathrm{D}$ for bone and other diseases has led to increased 25hydroxyvitamin $\mathrm{D}[25(\mathrm{OH}) \mathrm{D}]$ testing (D represents $\mathrm{D}_{3}$ and $\mathrm{D}_{2}$ forms). However, variability within and between methods and laboratories has often compromised correct diagnosis and the ability to compare results from different studies and national surveys [1-5]. Automated antibodybased, radioimmunoassays, high performance liquid chromatography (HPLC), and mass spectrometry methods for $25(\mathrm{OH}) \mathrm{D}$ testing are subject to variability issues that can arise from a variety of sources, such as differential detection of the $\mathrm{D}_{3}$ and $\mathrm{D}_{2}$ forms, interference by detection polyclonal antibodies, and nonspecific detection of other vitamin $\mathrm{D}$ metabolites such as the 3-epimer form of $25(\mathrm{OH}) \mathrm{D}$ [3epi-25(OH)D] and $24,25(\mathrm{OH})_{2} \mathrm{D}_{3}$. In addition, incomplete release of $25(\mathrm{OH}) \mathrm{D}$ from the vitamin $\mathrm{D}$ binding protein
(DBP) has been identified as a potential source of variability for both manual and automated immunoassays [6].

Establishing an immunoassay for $25(\mathrm{OH}) \mathrm{D}$ is challenging because the majority of the highly hydrophobic $25(\mathrm{OH}) \mathrm{D}$ is tightly bound (dissociation constant, $\mathrm{Kd}, 5 \times 10^{-8} \mathrm{M}$ ) to a vast excess of DBP from which it must be separated; almost no 25(OH)D is found "free" (non-protein bound) in the circulation, and less than $5 \%$ of the available DBP binding sites are occupied by vitamin $\mathrm{D}$ compounds [7]. In addition, DBP binds vitamin $\mathrm{D}_{3}$ along with other metabolites and vitamin $\mathrm{D}_{2}$, whose similar structures may be easier to release from DBP and difficult to differentiate; DBP has a higher affinity for vitamin $\mathrm{D}_{3}$ than other metabolites and vitamin $\mathrm{D}_{2}$ [8]; and generating specific antibodies against small antigenic molecules, such as $25(\mathrm{OH}) \mathrm{D}$, is difficult, but it is mandatory because the Vitamin D Standardization Program (VDSP) states that $25(\mathrm{OH}) \mathrm{D}$ assays should measure 
equimolar amounts of $25(\mathrm{OH}) \mathrm{D}_{3}$ and $25(\mathrm{OH}) \mathrm{D}_{2}$ (total vitamin D) [9]. Measuring total vitamin $\mathrm{D}$ is required because some supplements contain the $\mathrm{D}_{2}$ form, and not measuring $\mathrm{D}_{2}$ would lead to lower $25(\mathrm{OH}) \mathrm{D}$ values. In methods such as radioimmunoassay, $\mathrm{HPLC}$, and mass spectrometry, an initial extraction step with organic solvents releases all bound 25(OH)D from DBP [10-13]. However, organic solvents are not compatible with most automated immunoassays, and alternative releasing agents, which are proprietary, are used instead. Recent studies performed in populations with different levels of DBP have questioned the effectiveness of these proprietary releasing agents to completely free $25(\mathrm{OH}) \mathrm{D}$ from DBP [6].

The goal of this study was to examine the ability of the ADVIA Centaur Vitamin D Total assay by comparison with an LC-MS/MS method to accurately measure 25(OH)D levels in serum samples from healthy adults (endogenous) and healthy adults with exogenous DBP (endogenous + spiked) and from pregnant women and chronic kidney disease (CKD) patients receiving dialysis, who have higher and lower than normal serum levels of DBP, respectively $[7,14,15]$. The ADVIA Centaur Vitamin D Total assay is traceable to the NIST-Ghent reference measurement procedure (RMP) for vitamin D testing. (This version of the ADVIA Centaur Vitamin D Total assay is not currently available commercially in all regions, including the USA.)

\section{Materials and Methods}

In order to determine the influence of DBP on a vitamin $\mathrm{D}$ immunoassay, a study examining $\mathrm{DBP}$ as an endogenous interference, similar to how hemoglobin, cholesterol, or total protein would be measured, following Clinical and Laboratory Standards Institute (CLSI) Document EP7-A2 [16] was performed at the Siemens R\&D facility in Tarrytown, NY, USA. Human native DBP ( $>95 \%$ pure) was purchased from Athens Research \& Technology, Inc.

2.1. LC-MS/MS. The LC-MS/MS method used in this study is traceable to the Esoterix ID-LC-MS/MS method, which is traceable to NIST. The LC-MS/MS method performed at Siemens used the Waters Acquity H-class ultrahigh performance liquid chromatography (UPLC) and triple quadrupole (TQD) tandem mass spectroscopy (MS) with MassLynx and QuanLynx software (Waters Acquity TQD system, Waters Corporation, Manchester, UK). This method is able to separate, identify, and separately quantify the concentrations of $25(\mathrm{OH}) \mathrm{D}_{2}, 25(\mathrm{OH}) \mathrm{D}_{3}$, and 3-epi-25(OH) $\mathrm{D}_{3}$ in a serum sample. As reported by the manufacturer, the LC-MS/MS method demonstrated a dynamic assay range of 2.5-220 ng/mL (6.25$550 \mathrm{nmol} / \mathrm{L})\left(r^{2}>0.997\right)$. Three levels of $25(\mathrm{OH}) \mathrm{D}_{2}$ and $25(\mathrm{OH}) \mathrm{D}_{3}$ concentrations tested over five consecutive days yielded intra-assay coefficients of variation (CVs) of $\leq 7.7 \%$ and interassay precision CVs of $<12 \%$ for $25(\mathrm{OH}) \mathrm{D}_{2}$ and $25(\mathrm{OH}) \mathrm{D}_{3}$.

2.2. ADVIA Centaur Vitamin D Total Assay. The ADVIA Centaur Vitamin D Total assay used in this study is traceable to the Ghent University ID-LC-MS/MS 25(OH)D RMP. (This version of the assay is not currently available commercially in all regions, including the USA.) The Ghent University is a reference laboratory for the Vitamin D Standardization Program (VDSP). The sample reference material (SRM) used for the Ghent University method is traceable to the NIST SRM 2972 [4, 9, 17]. Recently, Siemens received confirmation from the Centers for Disease Control and Prevention (CDC) that the ADVIA Centaur Vitamin D Total assay is now a certified procedure of the Vitamin D Standardization-Certification Program (VDSCP). Certification was achieved by demonstrating that the total vitamin $\mathrm{D}[25(\mathrm{OH}) \mathrm{D}]$ results for the 40 VDSCP samples (10 quarterly challenges) agreed with the results from the ID-LC-MS/MS RMP method. The ADVIA Centaur Vitamin D Total assay achieved a mean bias of $0.3 \%$ (acceptance criterion was $\pm 5.0 \%$ ) and a mean imprecision of $5.5 \%$ (acceptance criterion was $<10.0 \%$ ). The ADVIA Centaur Vitamin D Total assay is a one-pass, 18-minute antibody competitive chemiluminescent immunoassay. Release of the $25(\mathrm{OH}) \mathrm{D}$ metabolites from the DBP is accomplished by denaturing and blocking agents. $25(\mathrm{OH}) \mathrm{D}$ in serum competes with a $25(\mathrm{OH}) \mathrm{D}$ analog (labeled with fluorescein) for an anti-25(OH)D monoclonal mouse antibody (labeled with acridinium ester). Detection occurs after the remaining anti25(OH)D monoclonal antibody (labeled with acridinium ester) complexes with vitamin D analog (labeled with fluorescein) and anti-fluorescein monoclonal antibody covalently bound to paramagnetic particles. Results are inversely related to $25(\mathrm{OH}) \mathrm{D}$ serum concentrations. The standardized assay demonstrates equimolar cross-reactivity with $25(\mathrm{OH}) \mathrm{D}_{2}$ $(104.5 \%)$ and $25(\mathrm{OH}) \mathrm{D}_{3}(100.7 \%)$, minimal cross-reactivity with 3-epimer-25(OH) $\mathrm{D}_{3}(1.1 \%)$, and a broad dynamic assay range of $4.2-150 \mathrm{ng} / \mathrm{mL}(10.5-375 \mathrm{nmol} / \mathrm{L})$ [18]. Precision was determined by assaying six samples twice a day in replicates of 4 , over 20 days ( $n=160$ replicates per sample) according to the Clinical and Laboratory Standards Institute (CLSI) protocol EP5-A2 [19]; the run-to-run CVs were in the range of $4.2 \%$ and $11.9 \%$ [18]. All samples were run in singlicate on both the LC-MS/MS and a single ADVIA Centaur system.

2.3. Sample Population. Clinical serum samples from 18 healthy adults were purchased from a commercial vendor (ProMedDx, Norton, MA, USA). Serum samples from 36 pregnant women in their third trimester and $40 \mathrm{CKD}$ hemodialysis patients were purchased from another commercial vendor (Research Sample Bank, Delray Beach, FL, USA).

2.4. Samples. Peripheral venous blood samples were collected, placed at $4^{\circ} \mathrm{C}$, and centrifuged; serum aliquots were prepared and stored for less than four months at $-20^{\circ} \mathrm{C}$ until analysis. Generally, no difference was found in the serum concentrations of DBP for men and women $[11,15]$.

2.5. Protocol. Serum samples were sent to Siemens Healthcare Diagnostics (Tarrytown, NY, USA) for DBP and $25(\mathrm{OH}) \mathrm{D}$ measurements. The serum samples from the 18 healthy adults were divided into five serum pools; each of 
TABLE 1: Serum concentrations of vitamin D binding protein in healthy subjects, DBP-spiked samples from healthy subjects, pregnant women, and dialysis patients.

\begin{tabular}{|c|c|c|c|c|c|}
\hline & $\begin{array}{l}\text { Number of } \\
\text { samples }\end{array}$ & $\begin{array}{c}\text { Average } \pm \text { SD } \\
(\mu \mathrm{g} / \mathrm{mL})\end{array}$ & Range $(\mu \mathrm{g} / \mathrm{mL})$ & $\begin{array}{l}\text { Median } \\
(\mu \mathrm{g} / \mathrm{mL})\end{array}$ & $\begin{array}{c}\text { Interquartile (IQ) } \\
\text { range }(\mu \mathrm{g} / \mathrm{mL})\end{array}$ \\
\hline Healthy not spiked (endogenous) & 5 & $348 \pm 106$ & $261-519$ & ND & ND \\
\hline Healthy (endogenous and endogenous + spiked) & 30 & $512 \pm 188^{\mathrm{a}}$ & 261-981 & ND & ND \\
\hline Healthy (endogenous + spiked) & 25 & $545 \pm 185^{\mathrm{a}}$ & $261-981$ & ND & ND \\
\hline Pregnancy & 36 & $415 \pm 245^{\mathrm{a}}$ & $82-875$ & 515 & $150-599$ \\
\hline Dialysis & 40 & $198 \pm 173$ & $63-1116$ & 142 & $100-262$ \\
\hline
\end{tabular}

${ }^{a} P<0.0001$ compared to the dialysis group.

ND: not determined.

DBP: vitamin D binding protein.

the four pools contained 4 individual serum samples and one pool contained 2 individual serum samples. The $25(\mathrm{OH}) \mathrm{D}$ concentrations in these five serum pools were measured by using a LC-MS/MS method at Siemens Healthcare Diagnostics, (Tarrytown, NY, USA) according to a protocol that allowed resolution of $25(\mathrm{OH}) \mathrm{D}_{2}$ and $25(\mathrm{OH}) \mathrm{D}_{3}$ from 3-epi$25(\mathrm{OH}) \mathrm{D}_{3}$. The LC-MS/MS values for the five individual pools (pools 1-5) resulted in mean $25(\mathrm{OH}) \mathrm{D}$ concentrations of $24,32,51,41$, and $75 \mathrm{ng} / \mathrm{mL}$, respectively. The endogenous levels of DBP were measured in each of the five serum pools using the Quantikine ELISA Vitamin D Binding Protein BP kit, DVDBP0 (R\&D Systems, Inc.). Subsequently, each of the five serum pools was divided into six aliquots, and DBP (ranging from 50 to $250 \mathrm{ug} / \mathrm{mL}$ in $50 \mathrm{ug} / \mathrm{mL}$ increments) was spiked into 5 of the 6 aliquots from each pool (Table 3). The DBP content in the resulting thirty samples was then reanalyzed to confirm higher DBP concentrations in spiked samples, and 25(OH)D measurements were performed according to routine procedures using the ADVIA Centaur Vitamin D Total assay traceable to the Ghent University ID-LC-MS/MS 25(OH)D RMP. (This version of the assay is not currently available commercially in all regions, including the USA.) Bias of $25(\mathrm{OH}) \mathrm{D}$ values to the original LC-MS/MS values was determined. In addition, the 36 clinical serum samples from third-trimester pregnancy patients and the 40 clinical serum samples from CKD patients were evaluated for endogenous DBP and 25(OH)D using the ADVIA Centaur Vitamin D Total assay; and bias of $25(\mathrm{OH}) \mathrm{D}$ values to the original LCMS/MS values was determined. Only four samples from pregnancy subjects had detectable $25(\mathrm{OH}) \mathrm{D}_{2}(3.2,5.2,8.0$, and $10.7 \mu \mathrm{g} / \mathrm{mL}$ ). Nineteen samples from dialysis patients had detectable $25(\mathrm{OH}) \mathrm{D}_{2}$ (range 1.6 to $35 \mu \mathrm{g} / \mathrm{mL}$ ), eight of which had levels above $10 \mu \mathrm{g} / \mathrm{mL}$. The 3 -epi- $25(\mathrm{OH}) \mathrm{D}_{3}$ was present at levels greater than $1.5 \mathrm{ng} / \mathrm{mL}$ in samples from 23 dialysis and 32 pregnancy subjects.

2.6. Statistics. Difference plots and bias values were obtained using Microsoft Excel (2010); Analyze-It add-in program in Excel was used to compare the different sets of data in order to obtain the $95 \%$ confidence interval (CI) and standard deviations (SD) for 95\% limits of agreement. Correlation plots and correlation and Deming regression analyses were generated using GraphPad Prism, version 6.

\section{Results}

The mean serum concentrations of DBP in healthy subjects (endogenous and endogenous + spiked), pregnant women, and dialysis patients are presented in Table 1. For the five serum pools, the average endogenous serum DBP concentration $( \pm \mathrm{SD}$ ) was $348 \pm 106 \mu \mathrm{g} / \mathrm{mL}$ (range 260.7 to $519.0 \mu \mathrm{g} / \mathrm{mL}$ ), which is consistent with the results of other studies $[6,20,21]$. For healthy serum samples spiked with DBP, the average DBP concentration was higher $(545 \pm$ $185 \mu \mathrm{g} / \mathrm{mL}$, range 261.2 to $980.6 \mu \mathrm{g} / \mathrm{mL}$ ) than endogenous levels. For pregnancy samples, the average DBP concentration was also greater $(415 \pm 245 \mu \mathrm{g} / \mathrm{mL}$, range 82.2 to $874.5 \mu \mathrm{g} / \mathrm{mL})$ than that for healthy serum samples. In contrast, for CKD patients receiving dialysis, the average DBP concentration was lower $(198 \pm 173 \mu \mathrm{g} / \mathrm{mL}$, range 63.4 to $1115.7 \mu \mathrm{g} / \mathrm{mL}$; median $142.1 \mu \mathrm{g} / \mathrm{mL}$ ) than levels in healthy serum and pregnancy samples.

The mean total serum 25(OH)D concentrations and range as measured by the LC-MS/MS method and the ADVIA Centaur Vitamin D Total assay are presented in Table 2. The mean $25(\mathrm{OH})$ D levels $( \pm \mathrm{SD})$ were $44.6 \pm 19.8$ and $44.8 \pm 20.1 \mathrm{ng} / \mathrm{mL}$ for healthy serum samples (endogenous), $44.6 \pm 18.0$ and $43.5 \pm 16.7 \mathrm{ng} / \mathrm{mL}$ for healthy (endogenous + spiked) serum samples, and $44.6 \pm 18.0$ and $43.7 \pm 17.0 \mathrm{ng} / \mathrm{mL}$ for both endogenous and endogenous + spiked healthy serum samples, and they were lower for pregnancy serum samples, $27.3 \pm 9.6$ and $25.3 \pm 8.7 \mathrm{ng} / \mathrm{mL}$, and dialysis serum samples, $28.1 \pm 14.8$ and $29 \pm 15.3 \mathrm{ng} / \mathrm{mL}$. Consistent with previous reports, no correlation was found between the DBP and 25(OH)D concentrations for serum from dialysis patients (Pearson's correlation coefficient $r=0.1$ ) [11, 14, 15]. Pregnancy samples demonstrated a positive correlation $(r=$ $0.35 ; P=0.013$ ) between serum concentrations of DBP and 25(OH)D for LC-MS/MS, but no correlation was found for ADVIA Centaur $(r=0.15 ; P=0.37)$. There were too few non-spiked healthy samples for valid 25(OH)D and DBP correlation assessment.

The overall average bias of all samples from healthy individuals (endogenous and endogenous + spiked) for the ADVIA Centaur Vitamin Total assay to the LC-MS/MS method was $-1.4 \%$; for all third-trimester pregnancy samples, the average bias was $-6.1 \%$; and for all renal dialysis samples, the average bias was $4.4 \%$. The results for bias, percent 
TABLE 2: Serum concentrations of 25(OH)D in healthy subjects, DBP-spiked samples from healthy subjects, pregnant women, and dialysis patients.

\begin{tabular}{|c|c|c|c|c|c|}
\hline & $\begin{array}{c}\text { Number of } \\
\text { samples }\end{array}$ & $\begin{array}{c}\text { ADVIA Centaur } \\
\text { Vitamin D Total assay } \\
\text { Average } \pm \text { SD } \\
(\mathrm{ng} / \mathrm{mL})\end{array}$ & $\begin{array}{c}\text { ADVIA Centaur } \\
\text { Vitamin D Total assay } \\
\text { Range }(\mathrm{ng} / \mathrm{mL})\end{array}$ & $\begin{array}{l}\text { LC-MS/MS } \\
\text { Average } \pm \text { SD } \\
\quad(\mathrm{ng} / \mathrm{mL})\end{array}$ & $\begin{array}{c}\text { LC-MS/MS } \\
\text { Range } \\
\text { (ng/mL) }\end{array}$ \\
\hline Healthy not spiked (endogenous) & 5 & $44.8 \pm 20.1^{\mathrm{a}}$ & $24.0-75.0$ & $44.6 \pm 19.8$ & $24.3-75.3$ \\
\hline $\begin{array}{l}\text { Healthy } \\
\text { (endogenous and endogenous }+ \text { spiked) }\end{array}$ & 30 & $43.7 \pm 16.7^{\mathrm{cdd}}$ & $22.9-75.3$ & $44.6 \pm 18.0^{\mathrm{e}}$ & $24.0-75.0$ \\
\hline Healthy (endogenous + spiked) & 25 & $43.5 \pm 16.7^{\mathrm{b}, \mathrm{d}}$ & $22.9-75.3$ & $44.6 \pm 18.0^{\mathrm{e}}$ & $24.0-75.0$ \\
\hline Pregnancy & 36 & $25.3 \pm 8.7$ & $3.7-40.8$ & $27.3 \pm 9.6$ & $4.0-44.9$ \\
\hline Dialysis & 40 & $29.0 \pm 15.3$ & $6.5-72.6$ & $28.1 \pm 14.8$ & $6.0-67.0$ \\
\hline
\end{tabular}

To convert 25(OH)D concentrations to nanomoles per liter (nmol/L), multiply by 2.5 .

${ }^{\mathrm{a}} P<0.05$ compared to the pregnancy group; ${ }^{\mathrm{b}} P<0.01$ compared to the dialysis group; ${ }^{\mathrm{c}} P<0.001$ compared to the dialysis group; ${ }^{\mathrm{d}} P<0.0001$ compared to the pregnancy group; ${ }^{\mathrm{e}} P<0.001$ compared to the pregnancy and dialysis groups.

DBP: vitamin D binding protein.

TABLE 3: Serum concentrations of DBP in healthy subjects and DBP-spiked samples from healthy subjects.

\begin{tabular}{|c|c|c|c|c|}
\hline $\begin{array}{l}\text { LC-MS/MS } \\
(\mathrm{ng} / \mathrm{mL})\end{array}$ & $\begin{array}{l}\text { Concentration of spiked } \\
\text { DBP in serum }(\mu \mathrm{g} / \mathrm{mL})\end{array}$ & $\begin{array}{c}\text { DBP } \\
(\mathrm{mg} / \mathrm{mL})\end{array}$ & $\begin{array}{c}\text { ADVIA Centaur } \\
(\mathrm{ng} / \mathrm{mL})\end{array}$ & $\begin{array}{l}\text { ADVIA Centaur bias to } \\
\text { LC-MS/MS }\end{array}$ \\
\hline 24 & & 276.9 & 24.3 & $1 \%$ \\
\hline 24 & 50 & 347.2 & 24.2 & $1 \%$ \\
\hline 24 & 100 & 385.5 & 23.5 & $-2 \%$ \\
\hline 24 & 150 & 334.9 & 24.3 & $1 \%$ \\
\hline 24 & 200 & 407.1 & 23.1 & $-4 \%$ \\
\hline 24 & 250 & 472.1 & 22.9 & $-5 \%$ \\
\hline 32 & & 301.6 & 31.6 & $-1 \%$ \\
\hline 32 & 50 & 339.1 & 34.8 & $9 \%$ \\
\hline 32 & 100 & 629.7 & 33 & $3 \%$ \\
\hline 32 & 150 & 446.8 & 34.8 & $9 \%$ \\
\hline 32 & 200 & 489.5 & 34.5 & $8 \%$ \\
\hline 32 & 250 & 584.4 & 31.9 & $0 \%$ \\
\hline 51 & & 260.7 & 53 & $4 \%$ \\
\hline 51 & 50 & 261.2 & 48.4 & $-5 \%$ \\
\hline 51 & 100 & 327.8 & 47.5 & $-7 \%$ \\
\hline 51 & 150 & 417.7 & 50.8 & $0 \%$ \\
\hline 51 & 200 & 593.3 & 49.1 & $-4 \%$ \\
\hline 51 & 250 & 486.2 & 45.7 & $-10 \%$ \\
\hline 41 & & 380.1 & 39.7 & $-3 \%$ \\
\hline 41 & 50 & 420.5 & 40.6 & $-1 \%$ \\
\hline 41 & 100 & 590.2 & 41.2 & $0 \%$ \\
\hline 41 & 150 & 747.3 & 38.5 & $-6 \%$ \\
\hline 41 & 200 & 738 & 40.9 & $0 \%$ \\
\hline 41 & 250 & 980.6 & 37.7 & $-8 \%$ \\
\hline 75 & & 519 & 75.3 & $0 \%$ \\
\hline 75 & 50 & 584.8 & 69.7 & $-7 \%$ \\
\hline 75 & 100 & 724.9 & 75.3 & $0 \%$ \\
\hline 75 & 150 & 788.4 & 73.4 & $-2 \%$ \\
\hline 75 & 200 & 731.3 & 67.7 & $-10 \%$ \\
\hline 75 & 250 & 789.7 & 73.1 & $-2 \%$ \\
\hline
\end{tabular}

DBP: vitamin D binding protein. To convert 25(OH)D concentrations to nanomoles per liter (nmol/L), multiply by 2.5 . 


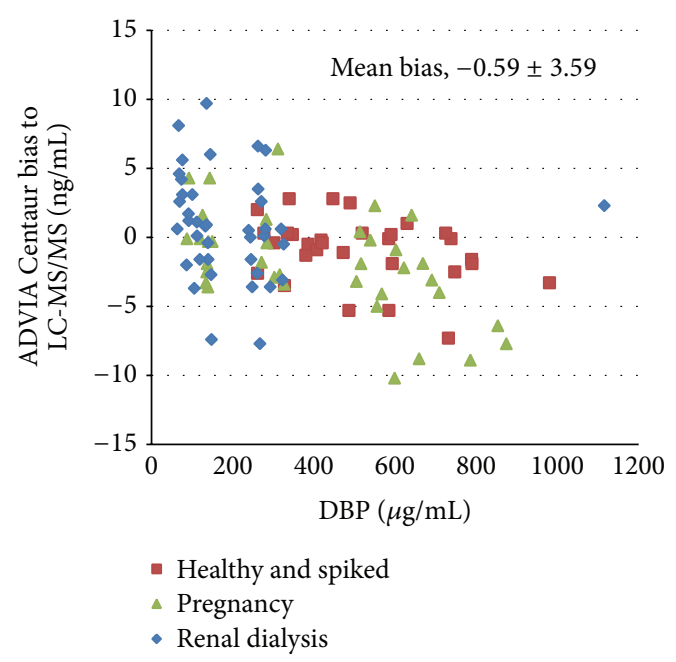

\begin{tabular}{c|c|c|c|c|c} 
& $n$ & Mean & $95 \%$ CI & SE & SD \\
\hline DBP spiked & 106 & 360.93 & $314.38-407.49$ & 23.480 & 241.742 \\
All samples (ng/mL) & 106 & -0.591 & $-1.28-0.10$ & 0.3487 & 3.5902
\end{tabular}

(a)

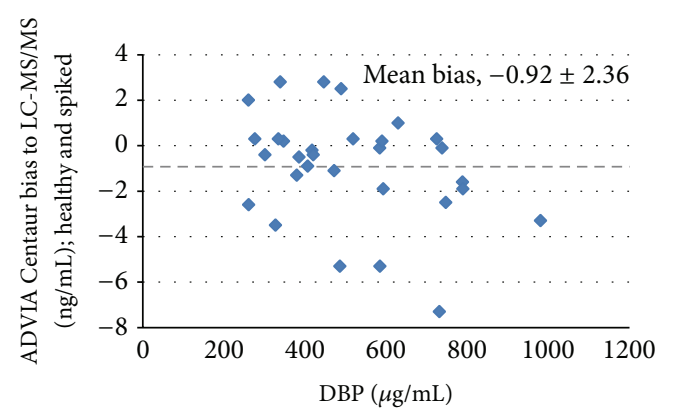

\begin{tabular}{c|c|c|c|c|c} 
& $n$ & Mean & $95 \%$ CI & SE & SD \\
\hline DBP spiked & 30 & 511.88 & $441.62-582.14$ & 34.354 & 188.163 \\
$\begin{array}{c}\text { Bias to LC-MS/MS } \\
\text { (ng/mL) }\end{array}$ & 30 & -0.92 & $-1.80--0.03$ & 0.431 & 2.363
\end{tabular}

(c)

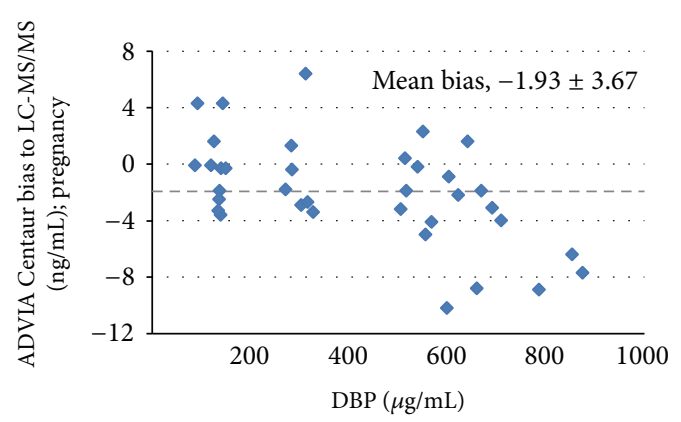

\begin{tabular}{c|c|c|c|c|c} 
& $n$ & Mean & $95 \%$ CI & SE & SD \\
\hline Pregnancy & 36 & 415.36 & $332.42-498.30$ & 40.855 & 245.131 \\
$\begin{array}{c}\text { Bias to LC-MS/MS } \\
(\mathrm{ng} / \mathrm{mL})\end{array}$ & 36 & -1.933 & $-3.18--0.69$ & 0.6119 & 3.6712
\end{tabular}

(e)

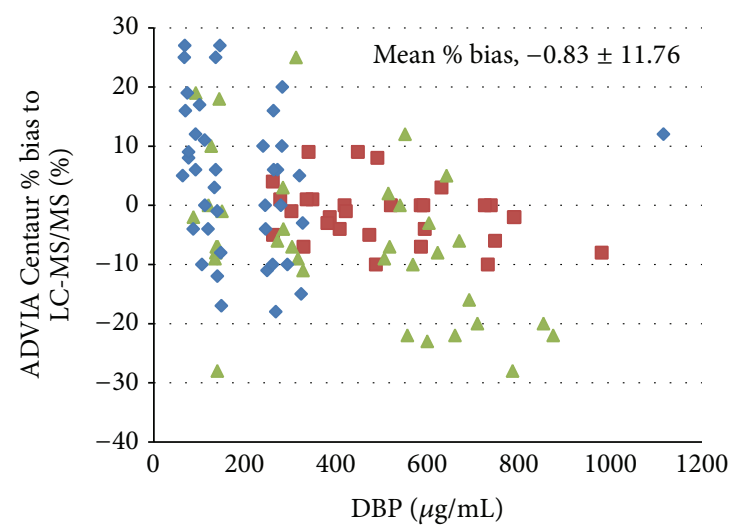

- Healthy and spiked

$\Delta$ Pregnancy

- Renal dialysis

\begin{tabular}{c|c|c|c|c|c} 
& $n$ & Mean & $95 \%$ CI & SE & SD \\
\hline DBP spiked & 106 & 360.93 & $314.38-407.49$ & 23.480 & 241.742 \\
All samples \% bias & 106 & -0.830 & $-3.10-1.43$ & 1.1423 & 11.7607
\end{tabular}

(b)

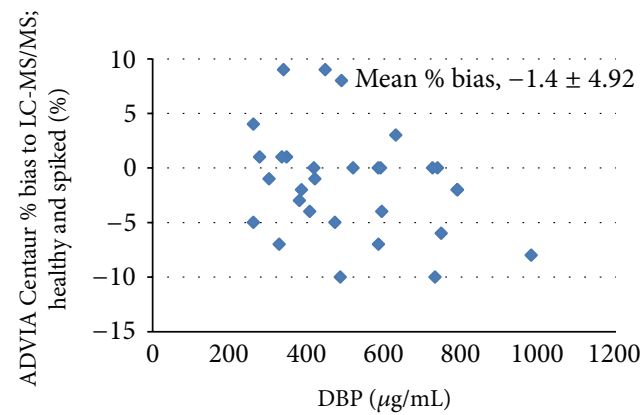

\begin{tabular}{c|c|c|c|c|c} 
& $n$ & Mean & $95 \%$ CI & SE & SD \\
\hline DBP spiked & 30 & 511.88 & $441.62-582.14$ & 34.354 & 188.163 \\
$\begin{array}{c}\text { Bias to LC-MS/MS } \\
(\%)\end{array}$ & 30 & -1.4 & $-3.20-0.47$ & 0.90 & 4.92
\end{tabular}

(d)

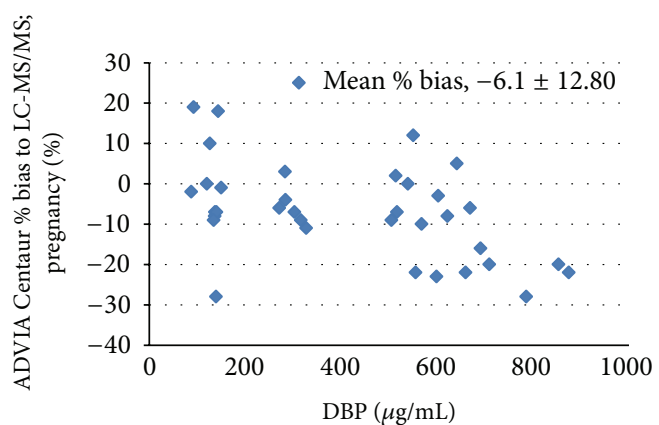

\begin{tabular}{c|c|c|c|c|c} 
& $n$ & Mean & $95 \%$ CI & SE & SD \\
\hline Pregnancy & 36 & 415.36 & $332.42-498.30$ & 40.855 & 245.131 \\
$\begin{array}{c}\text { Bias to LC-MS/MS } \\
(\%)\end{array}$ & 36 & -6.1 & $-10.47--1.81$ & 2.13 & 12.80
\end{tabular}

FIgURE 1: Continued. 


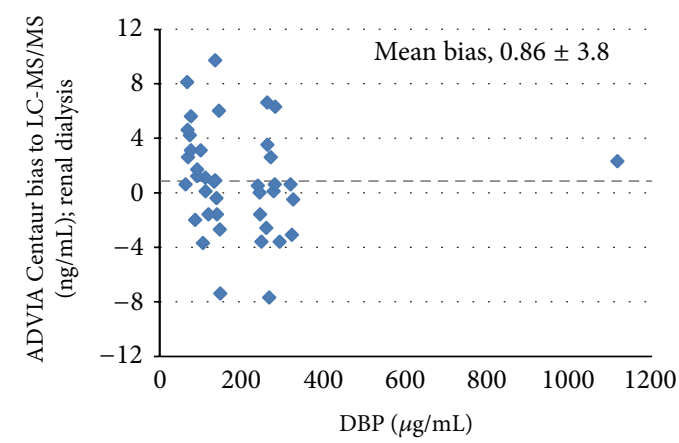

\begin{tabular}{c|c|c|c|c|c} 
& $n$ & Mean & $95 \%$ CI & SE & SD \\
\hline Renal dialysis & 40 & 198.74 & $143.50-253.98$ & 27.313 & 172.740 \\
$\begin{array}{c}\text { Bias to LC-MS/MS } \\
(\mathrm{ng} / \mathrm{mL})\end{array}$ & 40 & 0.86 & $-0.36-2.08$ & 0.603 & 3.815
\end{tabular}

(g)

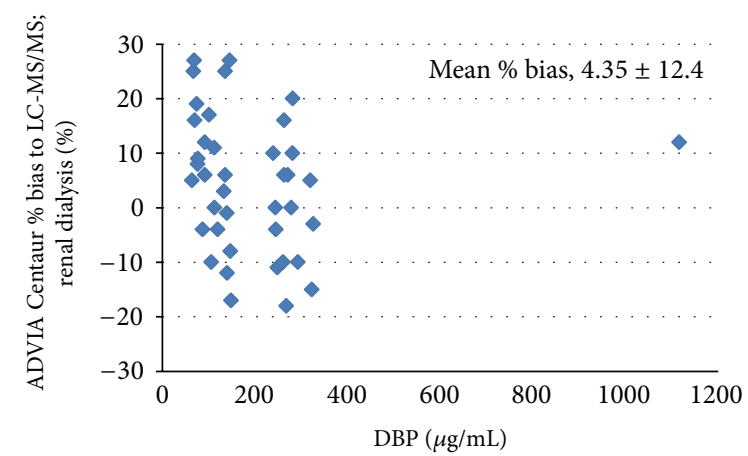

\begin{tabular}{c|c|c|c|c|c} 
& $n$ & Mean & $95 \%$ CI & SE & SD \\
\hline Renal dialysis & 40 & 198.74 & $143.50-253.98$ & 27.313 & 172.740 \\
Bias to LC-MS/MS & 40 & 4.350 & $0.38-8.32$ & 1.9604 & 12.3984 \\
$(\%)$ & & & & &
\end{tabular}

(h)

FIGURE 1: Bias and percent bias between the 25(OH)D results of the ADVIA Centaur Vitamin D Total assay and the LC-MS/MS method as a function of DBP concentration in healthy human serum pooled samples (endogenous and endogenous + spiked) (a, b, $c, d)$, pregnancy (third trimester) samples (a, b, e, f), and renal dialysis samples (a, b, g, h). The bias \pm 1.96 standard deviation (SD) represents the $95 \%$ limits of agreement. To convert $25(\mathrm{OH}) \mathrm{D}$ concentrations to nanomoles per liter (nmol/L), multiply by 2.5 .

bias, $95 \% \mathrm{CI}$, and SD (95\% limits of agreement $=1.96 \mathrm{SD})$ as a function of DBP concentration for each populationseparate and combined-are presented in Figure 1. When all populations were combined, positive bias (versus LCMS/MS) was observed at very low serum DBP concentrations and negative bias was observed at very high serum DBP concentrations (Figure 1).

With respect to dialysis samples with generally lower DBP concentrations, we do not know if uremic serum properties contributed to bias, and we question the validity of analyzing combined populations. Nevertheless, we examined how well the methods in subjects with serum DBP concentrations at extremes of the serum DBP concentration range (very low and very high) — for combined and separate populations (Figures 2, 3, and 4). Very low and very high serum DBP concentrations were defined as two SD below and above the mean for healthy subjects which is $348 \pm 106 \mu \mathrm{g} / \mathrm{mL}$; hence, the very low DBP group comprised samples having concentrations of $\leq 136 \mu \mathrm{g} / \mathrm{mL}$, and high DBP group comprised samples having concentrations of $\geq 560 \mu \mathrm{g} / \mathrm{mL}$. The middle range group had samples with DBP concentrations ranging from 137 to $559 \mu \mathrm{g} / \mathrm{mL}$. The following populations were analyzed: (1) healthy, spiked, pregnancy, and dialysis (Figure 2); (2) healthy (which had no low or high groups) [Figure 3(a)]; (3) healthy and spiked (which had no low group) [Figure 3(b)]; (4) spiked (which had no low group) [Figure 3(c)]; (5) pregnancy [Figure 4(a)]; (6) dialysis (which had no high group) [Figure 4(b)].

Analysis of 25(OH)D values for ADVIA Centaur and LCMS/MS as a function of low, medium, and high serum DBP concentrations demonstrated that correlations between the two methods were acceptable at low and high serum DBP levels for all populations analyzed (combined and separate) (Figures 2, 3, and 4), with pregnancy samples demonstrating the lowest correlation at very high serum DBP concentrations ( $r=0.87, P<0.0002$ ). Healthy samples (endogenous and endogenous + spiked) showed very good correlations and agreement between methods. The mean bias obtained for combined populations and each population separately for their low, medium, and high range DBP groups represented acceptable assay performance (Table 4$)$.

LC-MS/MS identified $25(\mathrm{OH}) \mathrm{D}_{3}, 25(\mathrm{OH}) \mathrm{D}_{2}$, and 3epi-25(OH) $\mathrm{D}_{3}$ in samples. Only four samples from pregnant subjects had detectable $25(\mathrm{OH}) \mathrm{D}_{2}(3.2,5.2,8.0$, and $10.7 \mu \mathrm{g} / \mathrm{mL})$. Nineteen samples from dialysis patients had detectable $25(\mathrm{OH}) \mathrm{D}_{2}$ (range 1.6 to $35 \mathrm{ng} / \mathrm{mL}$ ), eight of which had levels above $10 \mathrm{ng} / \mathrm{mL}$. The mean percent bias of the eight $25(\mathrm{OH}) \mathrm{D}_{2}$ samples which had greater than $10 \mathrm{ng} / \mathrm{mL}$ was $9.0 \pm 0.12 \%$ (mean $\pm \mathrm{SD}$ ), whereas the mean percent bias of the remaining samples was $3.0 \pm 0.12 \%$. Of the 40 dialysis patients, 17 had less than $1.5 \mathrm{ng} / \mathrm{mL} 3$-epi-25(OH)D $\mathrm{D}_{3}$ and 23 (58\%) had 3-epi-25(OH) $\mathrm{D}_{3}$ concentrations ranging from 1.7 to 3.6 (mean $\pm \mathrm{SD}, 2.5 \pm 0.57 \mathrm{ng} / \mathrm{mL}$ ). Of the 36 pregnancy subjects, four had less than $1.5 \mathrm{ng} / \mathrm{mL} 3$-epi-25(OH) $\mathrm{D}_{3}$ and $32(89 \%)$ had 3 -epi-25( $\mathrm{OH}) \mathrm{D}_{3}$ concentrations ranging from 1.6 to $6.3 \mathrm{ng} / \mathrm{mL}$ (mean $\pm \mathrm{SD}, 3.3 \pm 1.3$ ).

\section{Discussion}

This study addressed the influence of DBP on the accuracy of the ADVIA Centaur Vitamin D Total assay by comparison with an LC-MS/MS method. The ADVIA Centaur Vitamin $\mathrm{D}$ Total assay results in this study are traceable to IDLC-MS/MS 25(OH)D reference method procedure and the standard reference materials established by NIST and the University of Ghent $[4,9,17,22]$.

In healthy individuals, endogenous serum DBP concentration $(347.6 \mu \mathrm{g} / \mathrm{mL})$ was found to be within the range 


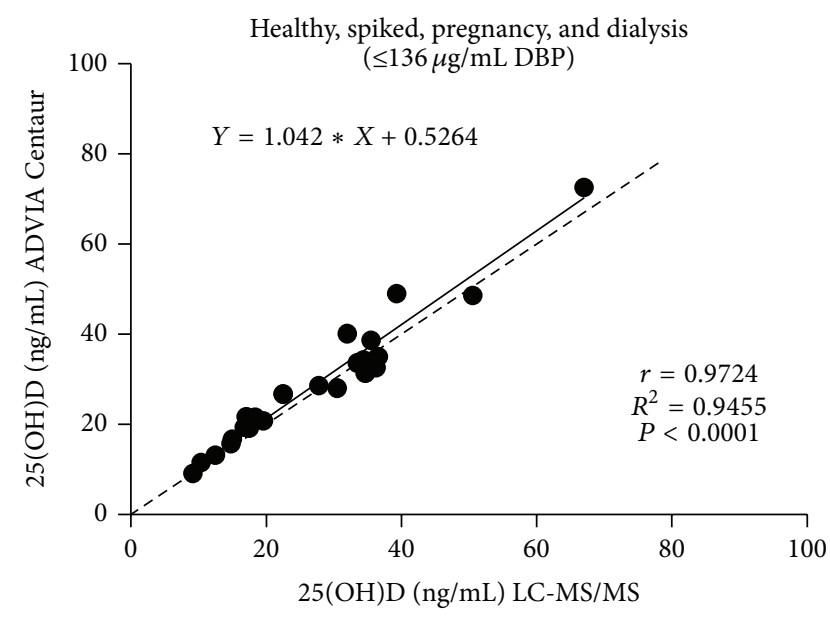

(a)

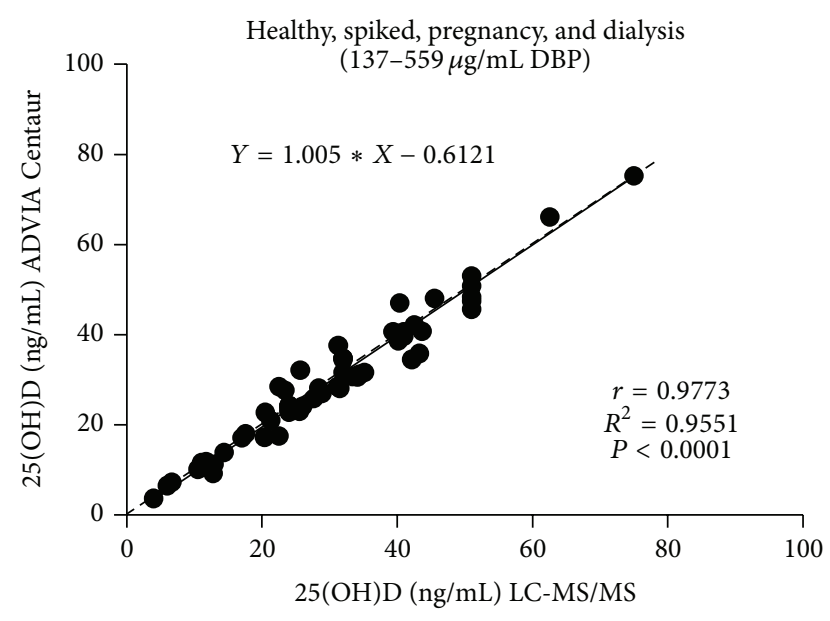

(b)

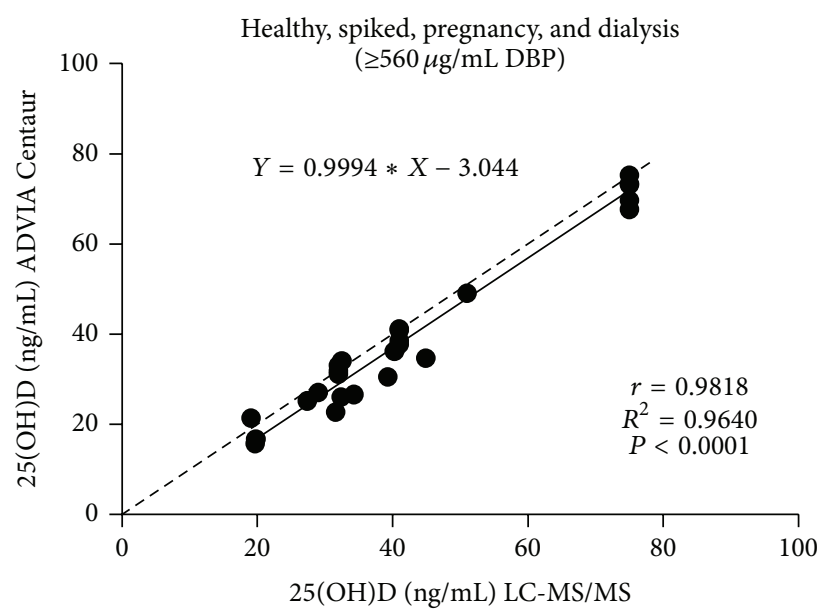

(c)

FIGURE 2: Correlation of 25(OH)D results obtained from the ADVIA Centaur Vitamin D Total assay and the LC-MS/MS method for combined normal human serum pooled samples (endogenous and endogenous + spiked), pregnancy (third trimester samples), and renal dialysis samples for (a) low, (b) medium, and (c) high DBP groups. Dotted line: line of identity. To convert 25(OH)D concentrations to nanomoles per liter $(\mathrm{nmol} / \mathrm{L})$, multiply by 2.5 .

reported by others $(300-600 \mu \mathrm{g} / \mathrm{mL})[20]$ and increased after DBP spiking $(545 \mu \mathrm{g} / \mathrm{mL})$. Despite the increase in DBP concentrations after spiking, 25(OH)D measurements in individual samples were equivalent between the two methods. There were no healthy (endogenous or endogenous + spiked) samples in the low DBP range, as defined by two SD values below the mean of healthy samples (i.e., $\leq 136 \mu \mathrm{g} / \mathrm{mL}$ ) (Figure 3 ). The high DBP range, as defined by two SD values above the mean of healthy samples (i.e., $\geq 560 \mu \mathrm{g} / \mathrm{mL}$ ), comprised twelve spiked samples (Figure 3), and 25(OH)D agreement was good between the methods for $25(\mathrm{OH}) \mathrm{D}$ values $(r=0.9927, P<0.0001$; bias $-3.0 \pm 3.98 \%)$. Thus, there was not a significant bias observed for the ADVIA Centaur for healthy samples (endogenous + spiked). This demonstrates that DBP concentrations as high as $980 \mu \mathrm{g} / \mathrm{mL}$ did not appear to interfere with the assay for this population. By comparison, endogenous serum DBP concentrations peaked at $519 \mu \mathrm{g} / \mathrm{mL}$ in healthy subjects. Because the use of
DBP-spiked samples may be suspect, these results will be confirmed in future studies which evaluate a greater number of samples from healthy subjects containing endogenous serum DBP concentrations in the higher range (although it is unlikely that normal healthy subjects exist with DBP concentrations that can be achieved at the high spiking concentrations).

Depending on hormonal status or disease state serum matrix components may be different, and the levels of DBP may be higher or lower than those of healthy individuals [14, 15]. In women who are receiving estrogen therapy and those who are pregnant, higher serum estrogen levels correlate with increases in circulating DBP and total $1,25(\mathrm{OH})_{2} \mathrm{D}$. During pregnancy, increased $1,25(\mathrm{OH})_{2} \mathrm{D}_{3}$ occurs in response to the growing calcium demands of the fetus [14, 15]. Consistent with these reports, the mean DBP concentration was greater $(415 \mu \mathrm{g} / \mathrm{mL})$ for samples from pregnant women than for those from healthy subjects $(347.6 \mu \mathrm{g} / \mathrm{mL})$ and dialysis patients 


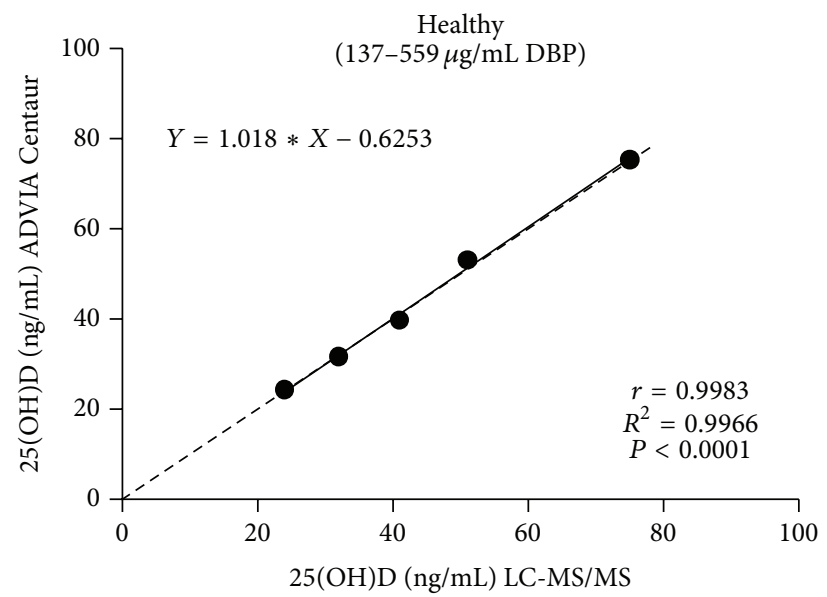

(a)
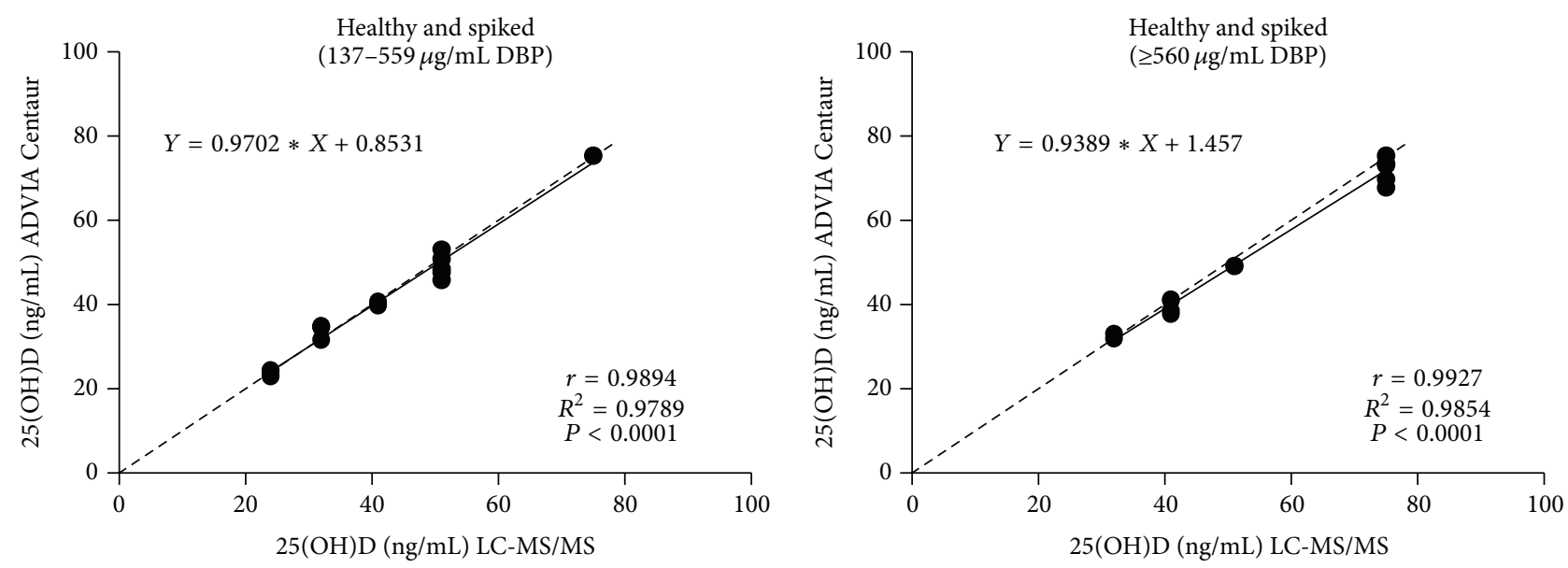

(b)
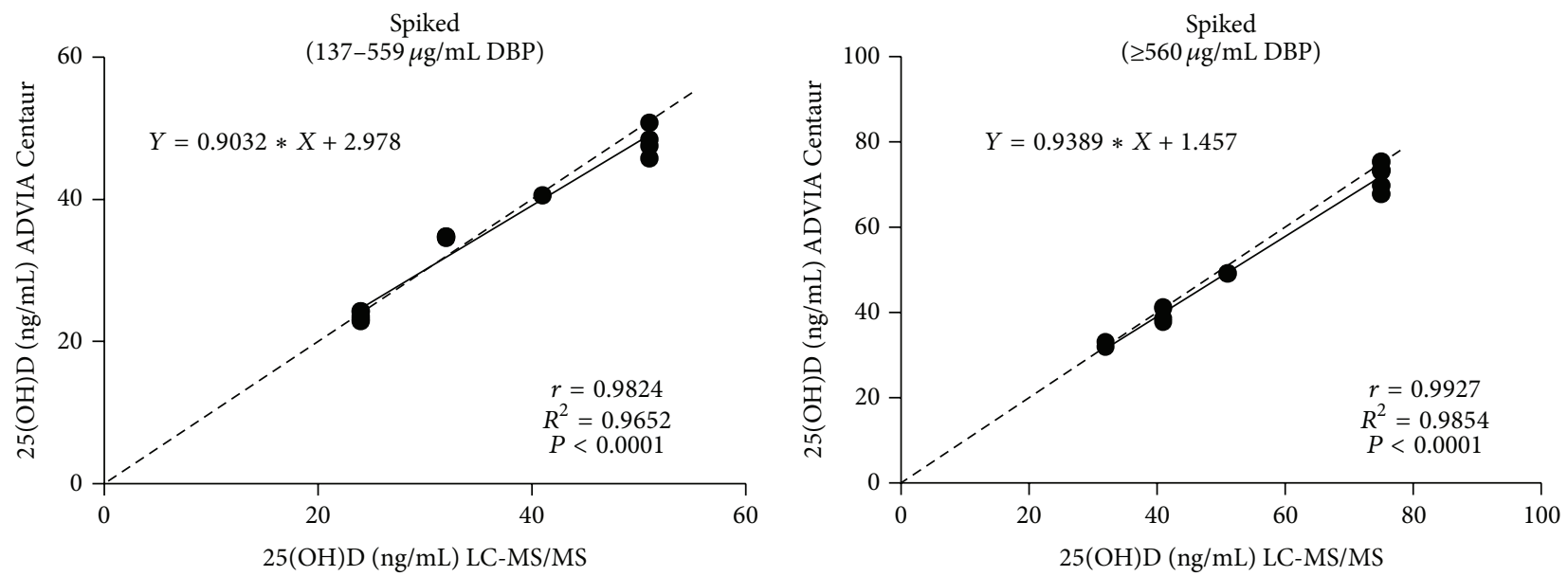

(c)

FIgURE 3: Correlation of 25(OH)D results obtained from the ADVIA Centaur Vitamin D Total assay and the LC-MS/MS method for normal human serum pooled samples: (a) endogenous, (b) endogenous and endogenous + spiked, and (c) endogenous + spiked. Dotted line: line of identity. To convert $25(\mathrm{OH}) \mathrm{D}$ concentrations to nanomoles per liter $(\mathrm{nmol} / \mathrm{L})$, multiply by 2.5 . 

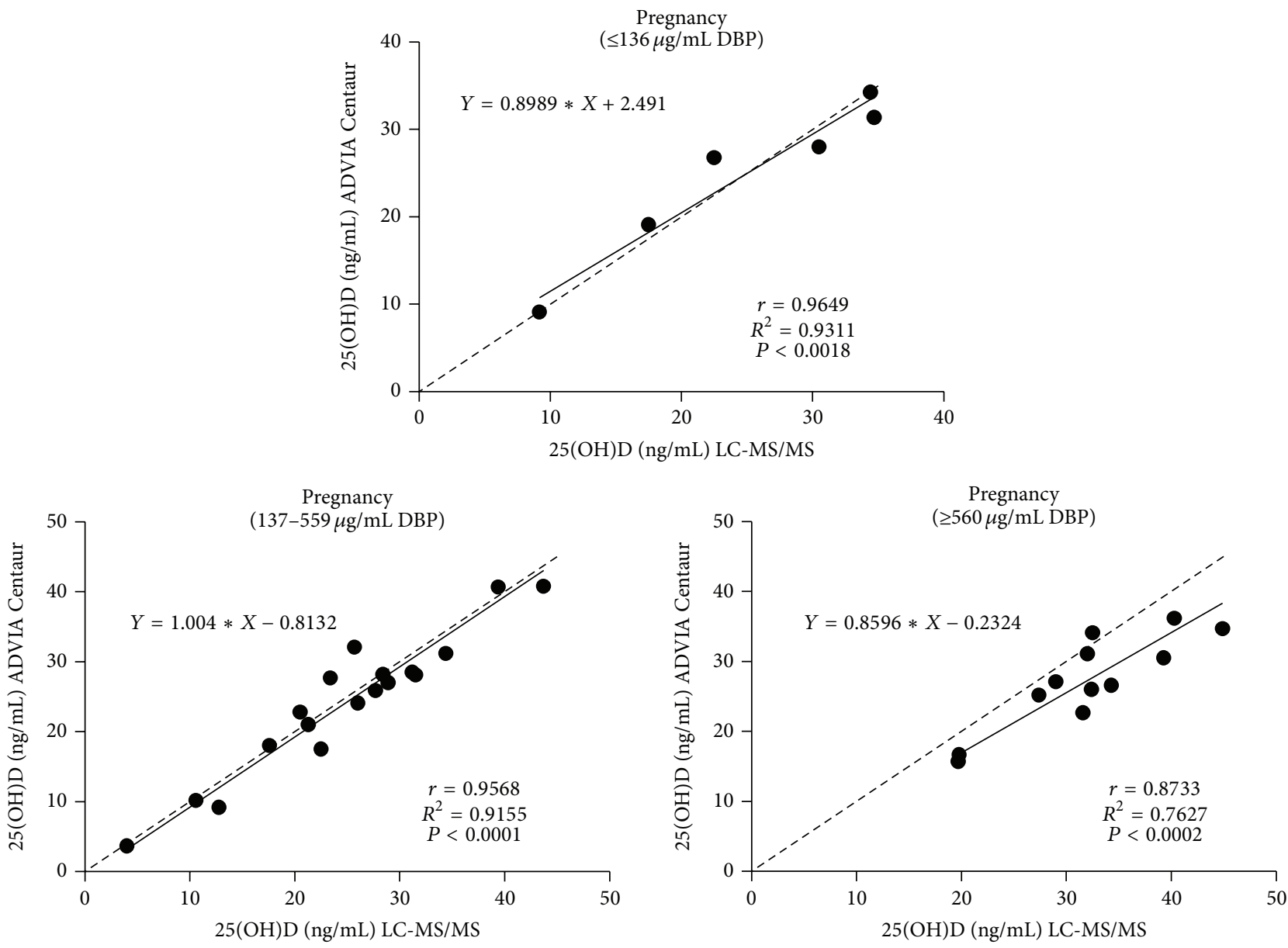

(a)
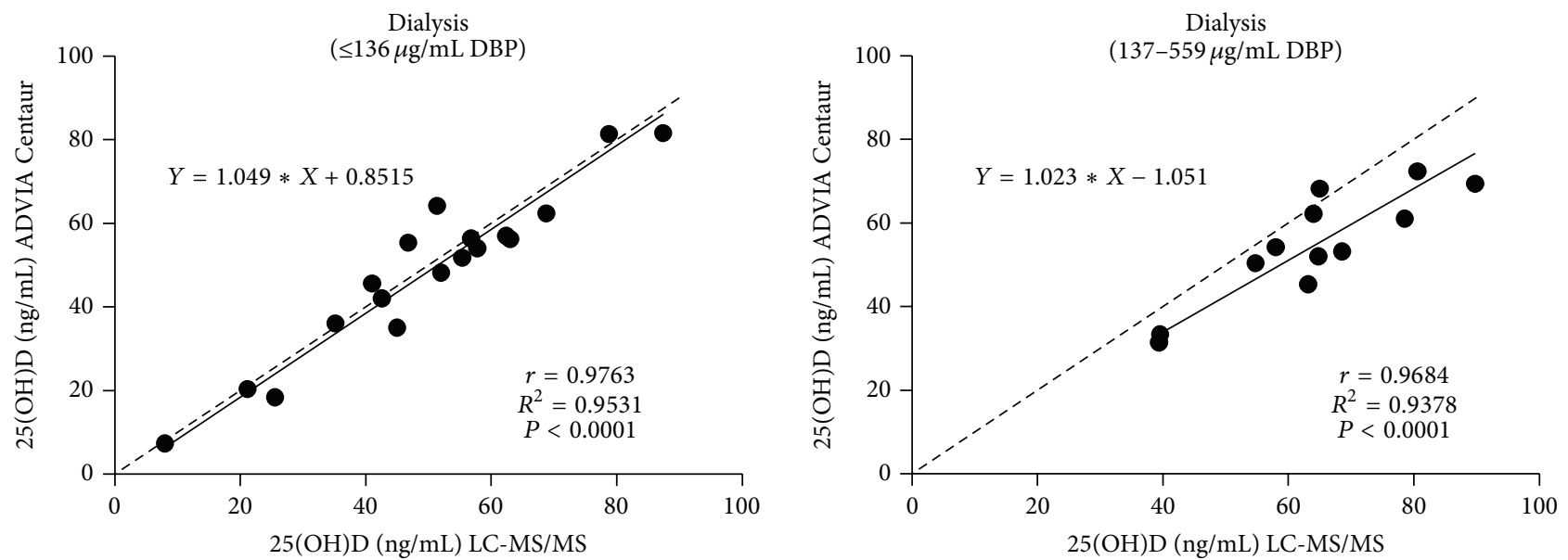

(b)

FIgure 4: Correlation of 25(OH)D results obtained from the ADVIA Centaur Vitamin D Total assay and the LC-MS/MS method for (a) pregnancy (third trimester) samples and (b) renal dialysis samples. Dotted line: line of identity. To convert $25(\mathrm{OH}) \mathrm{D}$ concentrations to nanomoles per liter (nmol/L), multiply by 2.5 .

$(198 \mu \mathrm{g} / \mathrm{mL})$. Despite the overall higher DBP concentrations in pregnancy serum, $25(\mathrm{OH}) \mathrm{D}$ results for those samples with low, medium, and high DBP concentrations demonstrated acceptable agreement between the ADVIA Centaur Vitamin
D Total assay and the LC-MS/MS method $(r=0.96, P<$ 0.0018 , bias $2.0 \pm 10.9 \% ; r=0.96, P<0.0001$, bias $-3.0 \pm$ 12.6\%; $r=0.87, P<0.0002$, bias $-14.0 \pm 9.9 \%$, resp.). Although samples in the low and medium DBP range showed 
TABLE 4: Mean bias $( \pm S D)$ compared to LC-MS/MS for the low, medium, and high range DBP groups for combined populations and each population separately: healthy and DBP-spiked, DBP-spiked, pregnant women, and dialysis patients.

\begin{tabular}{|c|c|c|c|}
\hline & $\begin{array}{c}\text { DBP } \\
\leq 136 \mu \mathrm{g} / \mathrm{mL}\end{array}$ & $\begin{array}{c}\text { DBP } \\
137-559 \mu \mathrm{g} / \mathrm{mL}\end{array}$ & $\begin{array}{c}\text { DBP } \\
\geq 560 \mu \mathrm{g} / \mathrm{mL}\end{array}$ \\
\hline \multicolumn{4}{|l|}{ Bias (ng/mL) } \\
\hline Combined populations & $\begin{array}{c}1.67 \pm 3.33 \\
(n=24)\end{array}$ & $\begin{array}{c}-0.45 \pm 3.07 \\
(n=57)\end{array}$ & $\begin{array}{c}-3.0 \pm 3.98 \\
(n=25)\end{array}$ \\
\hline Healthy (endogenous and endogenous + spiked) & & $\begin{array}{c}-2.78 \pm 2.12 \\
\quad(n=18)\end{array}$ & $\begin{array}{c}-1.88 \pm 2.47 \\
(n=12)\end{array}$ \\
\hline Healthy (endogenous + spiked) & & $\begin{array}{c}-0.45 \pm 2.40 \\
\quad(n=13)\end{array}$ & $\begin{array}{c}-1.88 \pm 2.47 \\
(n=12)\end{array}$ \\
\hline Pregnancy & $\begin{array}{c}0.017 \pm 2.76 \\
n=6\end{array}$ & $\begin{array}{c}-0.72 \pm 0.13 \\
\quad(n=18)\end{array}$ & $\begin{array}{c}-4.72 \pm 3.67 \\
(n=12)\end{array}$ \\
\hline Dialysis & $\begin{array}{c}2.23 \pm 3.38 \\
\quad(n=18)\end{array}$ & $\begin{array}{c}-0.38 \pm 3.91 \\
(n=21)\end{array}$ & $\begin{array}{c}2.30 \\
(n=1)\end{array}$ \\
\hline \multicolumn{4}{|l|}{$\%$ bias } \\
\hline Combined populations & $\begin{array}{c}8.0 \pm 10.99 \% \\
(n=24)\end{array}$ & $\begin{array}{c}-1.0 \pm 10.66 \% \\
\quad(n=57)\end{array}$ & $\begin{array}{c}-8.0 \pm 10.09 \% \\
\quad(n=25)\end{array}$ \\
\hline Healthy (endogenous and endogenous + spiked) & & $\begin{array}{c}0.0 \pm 5.30 \% \\
(n=18)\end{array}$ & $\begin{array}{c}-3.0 \pm 3.98 \% \\
(n=12)\end{array}$ \\
\hline Healthy (endogenous + spiked) & & $\begin{array}{c}0.0 \pm 6.10 \% \\
\quad(n=13)\end{array}$ & $\begin{array}{c}-3.0 \% \pm 3.98 \% \\
(n=12)\end{array}$ \\
\hline Pregnancy & $\begin{array}{c}2.0 \pm 10.9 \% \\
(n=6)\end{array}$ & $\begin{array}{c}-3.0 \pm 12.6 \% \\
(n=18)\end{array}$ & $\begin{array}{c}-14.0 \pm 9.9 \% \\
(n=12)\end{array}$ \\
\hline Dialysis & $\begin{array}{c}10.0 \pm 10.6 \% \\
(n=18)\end{array}$ & $\begin{array}{c}0.0 \pm 12.4 \% \\
(n=21)\end{array}$ & $\begin{array}{l}12.0 \% \\
(n=1)\end{array}$ \\
\hline
\end{tabular}

DBP: vitamin D binding protein. To convert 25(OH)D concentrations to nanomoles per liter (nmol/L), multiply by 2.5 .

less bias than those with very high DBP concentrations, the assay performance was acceptable for all groups. Four samples out of 36 contained measureable $25(\mathrm{OH}) \mathrm{D}_{2}$; it is unlikely that $25(\mathrm{OH}) \mathrm{D}_{2}$ influenced the assay bias because several samples lacking $25(\mathrm{OH}) \mathrm{D}_{2}$ demonstrated similar levels of bias. In contrast to a previous study that found higher $25(\mathrm{OH}) \mathrm{D}$ levels in pregnant women compared to nonpregnant healthy women, this study found overall lower levels in pregnant women; this difference may relate to differences in vitamin D supplementation [6].

Nephrotic syndrome and CKD predialysis and dialysis patients demonstrate diminished serum levels of the bioactive $1,25(\mathrm{OH})_{2} \mathrm{D}$, likely due, in part, to impaired renal synthesis, nutritional deficit, and lower $25(\mathrm{OH}) \mathrm{D}$ substrate levels [23-26]. Although some studies report no change in serum DBP levels in renal failure patients compared with healthy individuals, other studies demonstrate lower serum levels and increased DBP urinary excretion; lower serum concentrations of DBP likely reflect increased urinary loss due to proteinuria, which is a common finding in CKD patients $[15,27,28]$. In this study, the overall mean $25(\mathrm{OH}) \mathrm{D}$ level was equivalent between the ADVIA Centaur Vitamin D Total assay and the LC-MS/MS method and for the low and medium range DBP groups $(r=0.97$ overall; $r=$ 0.98 low range $\mathrm{DBP}$ group; $r=0.97$ middle range $\mathrm{DBP}$ group, $P<0.0001$; bias was $4.35 \pm 12.4 \%$ overall, $10.0 \pm$ $10.6 \%$ for the low range DBP group and $0.0 \pm 12.4 \%$ for the middle range DBP group, resp.), indicating acceptable performance of the ADVIA Centaur Vitamin D Total assay in the presence of DBP and uremic serum. It is not known whether unique components of uremic serum contributed to the bias observed. Nineteen samples from dialysis patients had detectable $25(\mathrm{OH}) \mathrm{D}_{2}$ (range 1.6 to $35 \mathrm{ng} / \mathrm{mL}$ ), eight of which had levels above $10 \mathrm{ng} / \mathrm{mL}$. The $25(\mathrm{OH}) \mathrm{D}_{2}$ containing samples appeared to contribute to the positive bias in this patient population. This result is consistent with the performance of the ADVIA Centaur Vitamin D Total assay which demonstrates a slight difference in recovery for $25(\mathrm{OH}) \mathrm{D}_{2}$ and $25(\mathrm{OH}) \mathrm{D}_{3}(104.5 \%$ versus $100.7 \%)$ as stated in the Instructions for Use Manual [18]. Only one uremic sample was found in the higher range $[1115.7 \mu \mathrm{g} / \mathrm{mL}$ $\mathrm{DBP} ; 19.1 \mathrm{ng} / \mathrm{mL} 25(\mathrm{OH}) \mathrm{D}_{3}$ by LC-MS/MS and $21.4 \mathrm{ng} / \mathrm{mL}$ $25(\mathrm{OH}) \mathrm{D}$ by ADVIA Centaur; $12 \%$ bias of ADVIA Centaur to LC-MS/MS]. Whether an error in DBP measurement was the cause for the unusually high DBP concentration is not known. Although the serum 25(OH)D concentrations in dialysis patients were lower than those found in healthy individuals, the values were approximately normal (according to the Endocrine Society Guidelines). This is likely due to patient adherence to vitamin D supplementation which is indicated for end-stage renal disease patients on dialysis. It is worth noting that lower levels of serum $25(\mathrm{OH}) \mathrm{D}$ concentrations in predialysis patients correlate with a greater risk of mortality [29]. This underscores the need to accurately evaluate and monitor serum $25(\mathrm{OH}) \mathrm{D}$ levels in the CKD patient population. 
A recent study implicated ineffective 25(OH)D-DBP extraction procedures as the cause of variability in an evaluation of five automated assays compared to an RMP LCMS/MS method [6]. The study, which included samples from healthy individuals, pregnant women, dialysis patients, and intensive care patients, found that the bias was, at least in part, dependent on DBP concentration. The ADVIA Centaur Vitamin D Total assay in the present study differed from the assay in the previous study in that it has a different standardization; this version is standardized with internal standards traceable to the NIST-Ghent VDSP RMP. This may have had some impact on why the results of this study differ from those previously reported.

\section{Conclusions}

The small positive bias found in renal dialysis patients with DBP concentrations below those found in normal healthy subjects and small negative bias found in pregnant subjects with DBP levels above those found in normal healthy subjects were within the acceptable range for the assay. Thus, for populations with different levels of DBP, the $25(\mathrm{OH}) \mathrm{D}$ results obtained by the ADVIA Centaur Vitamin D Total immunoassay were equivalent to the sum of $25(\mathrm{OH}) \mathrm{D}_{2}$ and $25(\mathrm{OH}) \mathrm{D}_{3}$ using the LC-MS/MS method-especially for individuals with serum DBP concentrations within the range for the healthy population (137 to $559 \mu \mathrm{g} / \mathrm{mL}$ ).

\section{Disclosure}

All authors are employees of Siemens Healthcare Diagnostics Inc.

\section{Conflict of Interests}

The authors declare that there is no conflict of interests regarding the publication of this paper.

\section{Acknowledgment}

This study was supported by Siemens Healthcare Diagnostics Inc.

\section{References}

[1] G. D. Carter, "Accuracy of 25-hydroxyvitamin D assays: confronting the issues," Current Drug Targets, vol. 12, no. 1, pp. 1928, 2011.

[2] G. D. Carter, J. L. Berry, E. Gunter et al., "Proficiency testing of 25-hydroxyvitamin D (25-OHD) assays," Journal of Steroid Biochemistry and Molecular Biology, vol. 121, no. 1-2, pp. 176$179,2010$.

[3] B. W. Hollis, "Editorial: the determination of circulating 25hydroxyvitamin D: no easy task," Journal of Clinical Endocrinology and Metabolism, vol. 89, no. 7, pp. 3149-3151, 2004.

[4] C. T. Sempos, H. W. Vesper, K. W. Phinney, L. M. Thienpont, P. M. Coates, and Vitamin D Standardization Program (VDSP), "Vitamin D status as an international issue: national surveys and the problem of standardization," Scandinavian Journal of
Clinical and Laboratory Investigation, vol. 72 , no. 243, pp. 32 40, 2012.

[5] A. M. Wallace, S. Gibson, A. de la Hunty, C. LambergAllardt, and M. Ashwell, "Measurement of 25-hydroxyvitamin $\mathrm{D}$ in the clinical laboratory: current procedures, performance characteristics and limitations," Steroids, vol. 75, no. 7, pp. 477488, 2010.

[6] A. C. Heijboer, M. A. Blankenstein, I. P. Kema, and M. M. Buijs, "Accuracy of 6 routine 25-hydroxyvitamin D assays: influence of vitamin D binding protein concentration," Clinical Chemistry, vol. 58, no. 3, pp. 543-548, 2012.

[7] N. E. Cooke and J. G. Haddad, "Vitamin D binding protein (Gcglobulin)," Endocrine Reviews, vol. 10, no. 3, pp. 294-307, 1989.

[8] B. W. Hollis, "Comparison of equilibrium and disequilibrium assay conditions for ergocalciferol, cholecalciferol and their major metabolites," Journal of Steroid Biochemistry, vol. 21, no. 1, pp. 81-86, 1984.

[9] L. M. Thienpont, H. C. M. Stepman, and H. W. Vesper, "Standardization of measurements of 25-Hydroxyvitamin D3 and D2," Scandinavian Journal of Clinical and Laboratory Investigation, vol. 72, no. 243, pp. 41-49, 2012.

[10] US Renal Data System, Annual Data Report: Atlas of End-Stage Renal Disease in the United States: International Comparisons, National Institutes of Health, National Institute of Diabetes and Digestive and Kidney Diseases, Bethesda, Md, USA, 2007.

[11] R. Bouillon, H. van Baelen, and P. de Moor, "The measurement of the vitamin D binding protein in human serum," Journal of Clinical Endocrinology and Metabolism, vol. 45, no. 2, pp. 225231, 1977.

[12] T. J. Gilbertson and R. P. Stryd, "High-performance liquid chromatographic assay for 25-hydroxyvitamin D3 in serum," Clinical Chemistry, vol. 23, no. 9, pp. 1700-1704, 1977.

[13] V. Justova, L. Starka, H. Wilczek, and V. Pacovsky, "A simple radioassay for 25 hydroxycholecalciferol without chromatography," Clinica Chimica Acta, vol. 70, no. 1, pp. 97-102, 1976.

[14] R. Bouillon, F. A. van Assche, H. van Baelen, W. Heyns, and P. de Moor, "Influence of the vitamin D-binding protein on the serum concentration of 1,25-dihydroxyvitamin D3. Significance of the free 1,25-dihydroxyvitamin D3 concentration," Journal of Clinical Investigation, vol. 67, no. 3, pp. 589-596, 1981.

[15] J. G. Haddad Jr. and J. Walgate, "Radioimmunoassay of the binding protein for vitamin D and its metabolites in human serum. Concentrations in normal subjects and patients with disorders of mineral homeostasis," Journal of Clinical Investigation, vol. 58, no. 5, pp. 1217-1222, 1976.

[16] Clinical and Laboratory Standards Institute (NCCLS), Interference Testing in Clinical Chemistry, NCCLS Document EP7-A2, Clinical and Laboratory Standards Institute, Wayne, Pa, USA, 2nd edition, 2005.

[17] H. C. M. Stepman, A. Vanderroost, K. van Uytfanghe, and L. M. Thienpont, "Candidate reference measurement procedures for serum 25-hydroxyvitamin D3and 25-hydroxyvitamin D2 by using isotope-dilution liquid chromatography-tandem mass spectrometry," Clinical Chemistry, vol. 57, no. 3, pp. 441-448, 2011.

[18] Siemens ADVIA Centaur XP Vitamin D Total (VitD) Assay, [Directional Insert 10699279_en rev a], Siemens Healthcare Diagnostics, Tarrytown, NY, USA, 2013.

[19] Clinical and Laboratory Standards Institute (NCCLS), Evaluation of Precision Performance of Quantitative Measurement Methods, NCCLS Document EP5-A2, Clinical and Laboratory Standards Institute, Wayne, Pa, USA, 2nd edition, 2004. 
[20] M. Kawakami, C. B. Blum, R. Ramakrishnan, R. B. Dell, and D. S. Goodman, "Turnover of the plasma bindng protein for vitamin D and its metabolites in normal human subjects," Journal of Clinical Endocrinology and Metabolism, vol. 53, no. 6, pp. 1110-1116, 1981.

[21] M. Speeckaert, G. Huang, J. R. Delanghe, and Y. E. C. Taes, "Biological and clinical aspects of the vitamin D binding protein (Gc-globulin) and its polymorphism," Clinica Chimica Acta, vol. 372, no. 1-2, pp. 33-42, 2006.

[22] W. G. Miller, G. L. Myers, M. L. Gantzer et al., "Roadmap for harmonization of clinical laboratory measurement procedures," Clinical Chemistry, vol. 57, no. 8, pp. 1108-1117, 2011.

[23] W. Al-Badr and K. J. Martin, "Vitamin D and kidney disease," Clinical Journal of the American Society of Nephrology, vol. 3, no. 5, pp. 1555-1560, 2008.

[24] E. A. González, A. Sachdeva, D. A. Oliver, and K. J. Martin, "Vitamin D insufficiency and deficiency in chronic kidney disease: a single center observational study," The American Journal of Nephrology, vol. 24, no. 5, pp. 503-510, 2004.

[25] R. E. LaClair, R. N. Hellman, S. L. Karp et al., "Prevalence of calcidiol deficiency in CKD: a cross-sectional study across latitudes in the United States," The American Journal of Kidney Diseases, vol. 45, no. 6, pp. 1026-1033, 2005.

[26] S. Williams, K. Malatesta, and K. Norris, "Vitamin D and chronic kidney disease," Ethnicity \& Disease, vol. 19, no. 4, supplement 5, pp. S5-8-S5-11, 2009.

[27] K. M. Thrailkill, C. Jo, G. E. Cockrell, C. S. Moreau, and J. L. Fowlkes, "Enhanced excretion of vitamin D binding protein in type 1 diabetes: a role in vitamin D deficiency?" Journal of Clinical Endocrinology and Metabolism, vol. 96, no. 1, pp. 142149, 2011.

[28] H. J. C. van Hoof, R. G. L. de Sévaux, H. van Baelen et al., "Relationship between free and total 1,25-dihydroxyvitamin $\mathrm{D}$ in conditions of modified binding," European Journal of Endocrinology, vol. 144, no. 4, pp. 391-396, 2001.

[29] R. Mehrotra, D. A. Kermah, I. B. Salusky et al., "Chronic kidney disease, hypovitaminosis D, and mortality in the United States," Kidney International, vol. 76, no. 9, pp. 977-983, 2009. 


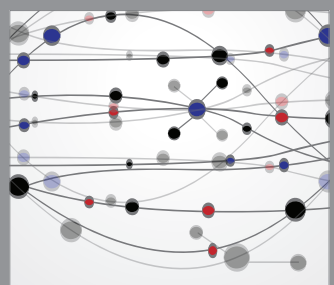

The Scientific World Journal
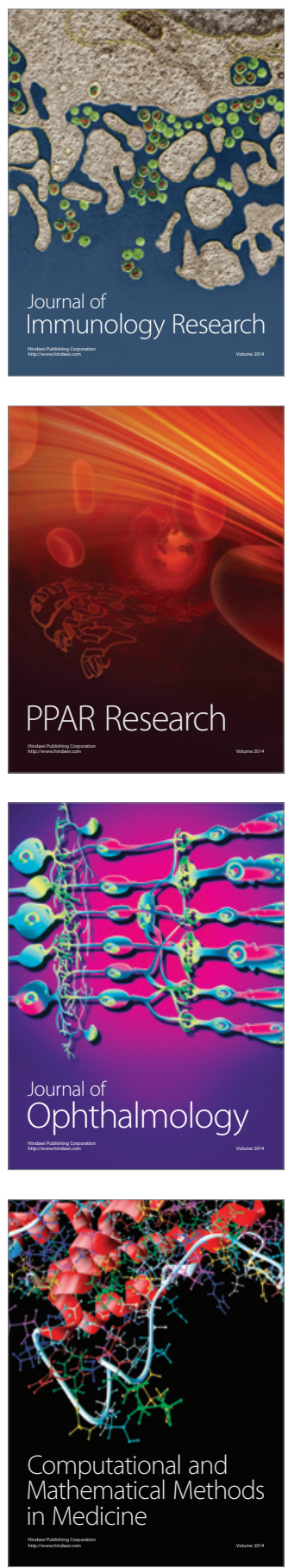

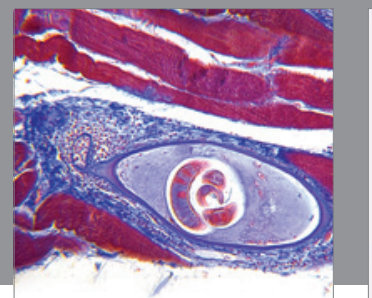

Gastroenterology

Research and Practice
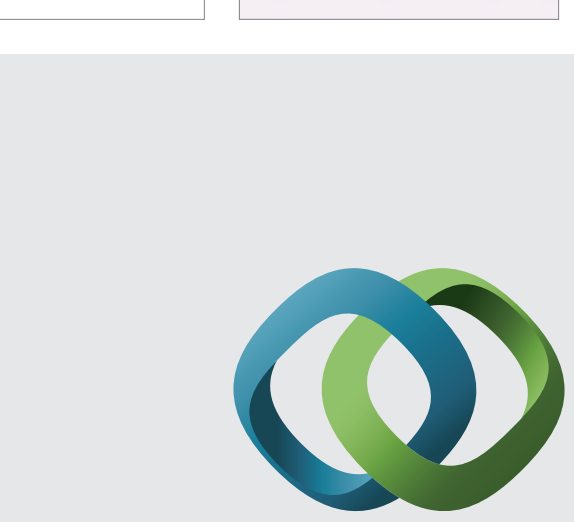

\section{Hindawi}

Submit your manuscripts at

http://www.hindawi.com
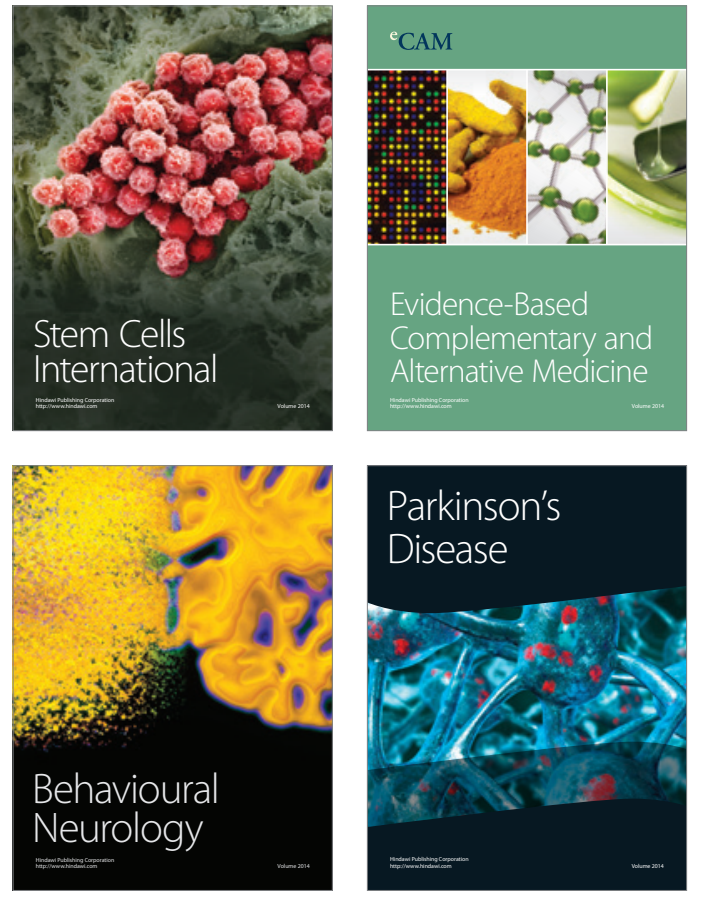
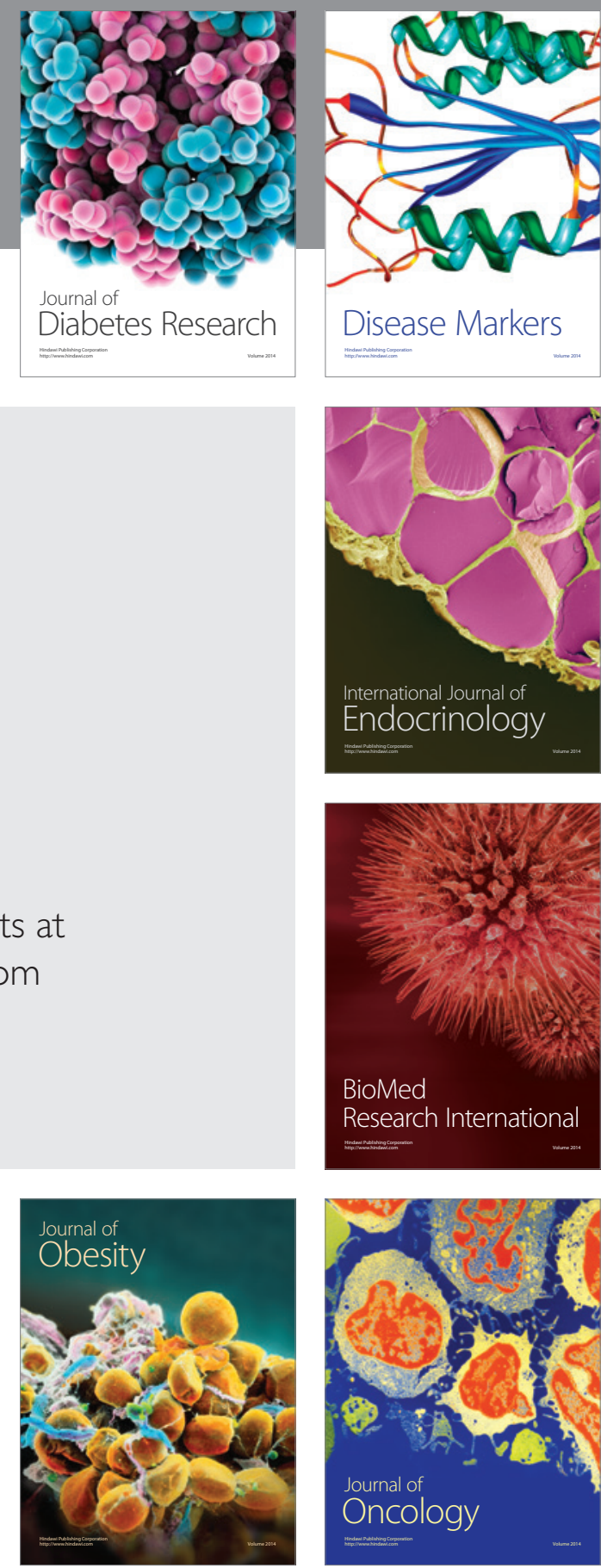

Disease Markers
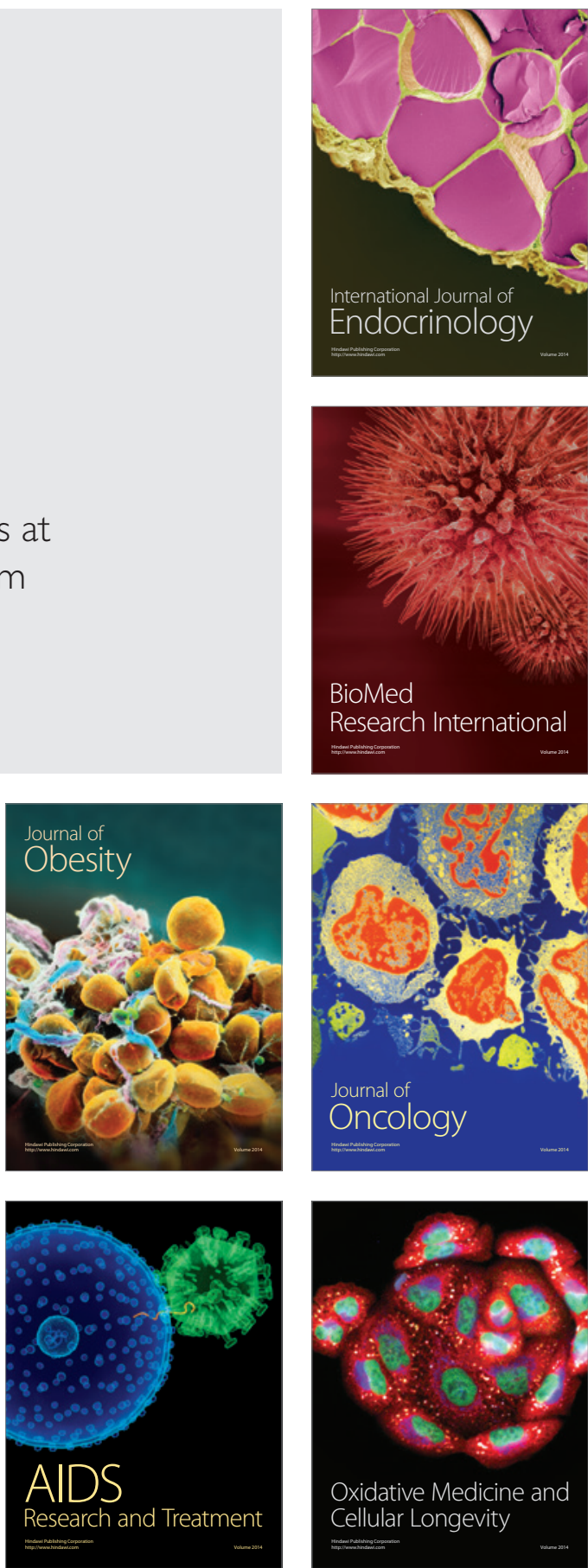